The Economic Journal of Nepal, Vol. 40, No. 1, 2, 3 \& 4, Jan-Dec 2017 (Issue N0. 148) @ CEDECON-TU

\title{
Trade War between China and USA: Implications to Nepal
}

\author{
Mukti Bahadur Khatri ${ }^{1}$
}

\begin{abstract}
The study examines the dynamic relationship along with disputes between the trade of China and the United States of America (U.S.A.). The study used a comparative analysis by investigating relative changes in the position of the foreign trade since 1960 A.D. On the basis of more than 50 years observations, there is a significant relationship between foreign trade of China and the U.S.A. Similarly, there are different causes of trade disputes between china and the U.S.A.. Its comparative advantage is that it can produce goods for lower costs than other countries. So, recent days, American companies cannot compete with low costs of China. Another reason is the view of President Donald J. Trump like 'The trade wars are good and easy to win'. In short run, trade wars have a positive impact on trade, but in the long term, it makes slow rate of economic growth, employment and weak the protected domestic industry. Similarly, it affects both economies of China and the U.S.A. and also promotes regional trade and dumping policy. Accordingly, exports base of Nepal is weak and its exports to China are being affected due to trade wars, despite the fact that trade to the United States does not affect.
\end{abstract}

Key words: China, USA, Nepal, Foreign trade, Exports, Imports, and Trade wars.

\section{Introduction}

Trade is a voluntary exchange of goods and services as per need of people and country. It is essential for capital accumulation within a country which is proved by trading policy of China, USA, Japan and Europe from the mercantile period up to now. A trade war is known as a situation when a nation imposes trade barriers (i.e. tariffs or quotas) on foreign goods/ services and trading partners also used similar forms of protection in trade. As it causes, a trade war and that reduces foreign trade. One of the most important economic expansions of the last 20 years is integration of China to the global trading system. The share of imports from China between 1990 and 2010 rose from 2 to 11 percent in the world market. For the U.S.A., it was even larger and rising from 3 to 19 percent (Auer \& Fischer, 2010). It has transformed of more than a tenfold increase in the share of U.S.A. in manufacturing expenditure on Chinese goods. Therefore, trade boom occurred after the accession of China to the World Trade Organization (WTO) in 2001. It has lead to reduce trade costs faced by Chinese exporters as China obtained permanent 'Most Favored Nation (MFN)' status with accession that ended the annual American threats to impose high tariffs. Accordingly, the

1 Mr. Khatri is a Lecturer in Economics at Trichandra Multiple Campus, Ghantaghar, T.U., Nepal. Email: muktikc01@gmail.com. 
contribution of China to its exports boom to the U.S.A. through a reduction in American trade policy uncertainty and U.S. applied trade barriers toward China remained largely unchanged at that time. In 2000, the average tariff of U.S.A. to MFN was 4 percent. But if China had lost its MFN status, it would have faced an average tariff of 31 percent (Handley \& Limao, 2017). Due to MFN status has been revoked by the U.S.A., it would have gone back to their old ways to tariff levels and a trade wars have been developed.

Therefore, relative economy growth of China in comparison to the U.S.A. and MFN facilities cause the most concern for trade disputes. While in 1978, GDP of China was far behind that of the USA. Today, it ranks first in the world economy in terms of purchasing power parity (PPP). So, in recent days, trade relation between China and the U.S.A. has been uneasy and politically sensitive. Similarly, the role of China on the global stage has grown to be even more significant in the course of the recent financial system. Therefore, it is widely acknowledged that with the rise of China, the bilateral relationship between China and the U.S.A. will be a crucial determinant of the direction of international trade in the new century. Accordingly, it is important to understand that the trade relations and impact of China and U.S. A. increasing interdependence on the global market. The study, instead, is explored the economic ties and wars between China and the U.S.A. from a more holistic perspective by providing an economic analysis of their trade relations and disputes under bilateral and multilateral frameworks along with implications of their importance to the bilateral relationship.

\section{Objective of the Study}

The general objective of the study is to consider the implications of trade wars between China and the U.S.A. The specific objectives of the study are as of:

- $\quad$ To identify the trade relations between China and the U.S.A.

- To find out the causes and consequences of trade disputes.

- To locate effects of such trade disputes in Nepal.

\section{Methodology}

The methodological approach to study the relationship of foreign trade between China and the U.S.A. is based on the trade development theory. A secondary source of data collection is employed for the study and compromise of yearly observations of macroeconomic variables obtained from Journal of Finance, American Economic Review, Journal of Economic Surveys, Economic Journal of Nepal, The Financial Review, IMF and The World Bank working papers, and various journal, articles, and working papers from Google scholar.

The study also focused on an extensive literature review covering relevant international level studies and reports of relevant organizations by using the data from 1960 AD to 1917 AD. So, the study is ex-post facto in nature. In addition, newspapers, conference proceedings, and other sources of information are explored. Descriptive statistics like mean, standard deviation, maximum and minimum value is used to provide summary information about the distribution, variability, and central tendency of selected variables. Similarly, construct error is minimized by using reliable and well defined measuring units. There is also consistency between measurements in a series under same precondition. Therefore, the study minimized systematic as well as variable error for reliability and validity. 


\section{Findings}

When a nation imposes trade barriers (i.e. tariffs or non-tariffs i.e. quotas, quarantine) on foreign goods/services and trading partners against with similar forms of protection in trade causes a trade war and that reduces international trade. It begins when any nation attempts to protect a domestic industry to create more employment. In the short run, it has positive impact on trade, which helps to become cheaper for domestic products thereby increases profit of domestic producers. But in the long run, it causes inflation when tariffs increase the prices of imports and that slowdowns potential economic growth for all countries involved. So, trade war costs growth and employment.

\section{U.S.A. Trade War with China}

In 2017, the U.S.A. exported \$ 130 billion to China while imports from china were US \$ 506 billion, causes huge trade deficit and creates threatened to the economy of the U.S.A. (Amadeo, 2017). In solar equipment manufacturing, China is a world leader. The WTO ruled that the United States didn't have a case in levying the tariff. Even if President Trump imposed tariffs and quotas on Chinese solar panels and washing machines, then it begins. So, China cased complaint with the WTO. Similarly, the Trump Administration upped the tariffs on US \$ 60 billion of imports from China and it would limit U.S. technology transfers to Chinese companies. China wants foreign companies who wish for to sell products in China to share their trade secrets with domestic companies. As said by Trump Administration, China uses cyber theft, espionage, and government pressure to obtain leading-edge technology. Accordingly, China also imposed tariffs by US \$ 3 billion in U.S. fruits, pork, recycled aluminum, and steel pipes. For the dispute settlements, the Trump Administration began quietly negotiating with Chinese trade officials with focused on requests. It would like China to reduce its tariffs on U.S. automobiles, China to import more U.S. semi-conductors.

Again, the Trump Administration imposes tariffs on US $\$ 50$ billion in Chinese imported electronics, aerospace, and machinery. China reacted and announced 25 percent tariffs on US $\$ 50$ billion of U.S. exports to China. Chinese tariffs strategically targeted 106 products. China also penalized U.S. exports of sorghum and Boeing airplanes. It targeted industries located in states that supported Trump in their election in 2016. The U.S.A. claimed that China stops subsidizing the 10 industries prioritized in its 'Made in China - 2025' plan. These include robotics, aerospace, and software. China also plans to be the top primary artificial intelligence center of the world by 2030 . Accordingly, trade disputes gradually transformed into trade war.

\section{Gross Domestic Product}

The strong economic growth of China since many years was associated with an acceleration of its foreign trade with rising domestic and external surplus. In 1990 A.D., China produced only 3 percent of global output by value but in 2017 A.D. it was tremendously increased and becomes 25 percent. The ratio of global GDP growth in terms of US $\$$ in concerned study periods has been increased overtime. It can be explained as below. 
Table 1: GDP of China, U.S.A. and Nepal (in billions U.S. \$)

\begin{tabular}{|l|c|c|c|}
\hline Years / Countries & China & USA & Nepal \\
\hline 1960 & 59.72 & 543.30 & 0.51 \\
\hline 1970 & 92.61 & 1075.88 & 0.87 \\
\hline 1980 & 191.15 & 2862.51 & 1.95 \\
\hline 1990 & 360.86 & 5979.59 & 3.63 \\
\hline 2000 & 1211.35 & 10284.78 & 5.49 \\
\hline 2010 & 6100.63 & 14964.37 & 16.03 \\
\hline 2016 & 11190.99 & 18624.48 & 21.14 \\
\hline
\end{tabular}

Source: World Development Indicators, World Bank, 2017.

The table 1 shows that GDP has been increased continuously from 1960 to 2016, but increasing ratio of China is more than U.S.A. and Nepal. The GDP of China increases two times more than in every 10 years.

Table 2: Annual Growth Rate of GDP (in percent)

\begin{tabular}{|c|c|c|c|}
\hline Years / Countries & China & USA & Nepal \\
\hline 1960 & NA & NA & NA \\
\hline 1961 & -27.27 & 2.30 & 1.91 \\
\hline 1970 & 19.30 & 3.21 & 2.58 \\
\hline 1980 & 7.81 & -0.25 & -2.32 \\
\hline 1990 & 3.91 & 1.92 & 4.64 \\
\hline 2000 & 8.50 & 4.10 & 6.20 \\
\hline 2010 & 10.64 & 2.53 & 4.82 \\
\hline 2016 & 6.70 & 1.49 & 0.42 \\
\hline
\end{tabular}

Source: World Development Indicators, World Bank, 2017.

The table 2 shows that annual percent of GDP growth rate of China is significantly higher than U.S.A. and Nepal. In 1970, it was 19.30 percent and after 1990, it has been almost more than 6 percent.

Figure 1: Annual Growth of GDP (in Percent)

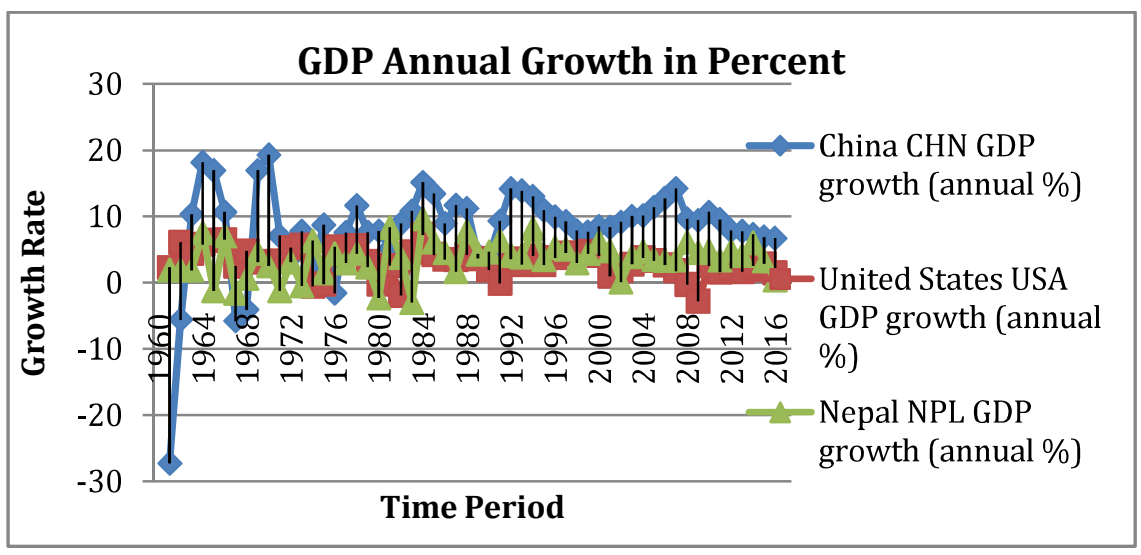

Source: World Development Indicators, World Bank, 2017. 
The figure 1 shows that annual percent of GDP growth rate of China has more fluctuations in comparison to U.S.A. and Nepal. But after 1990, it is almost stable. Similarly, annual growth rate of China is higher than the U.S.A. and Nepal. Similarly, regarding industrial production growth rate, real GDP growth rate and gross national saving (GNS) of China are also higher than the U.S.A. in comparison of three years. Accordingly, the contribution of agriculture in GDP of both countries of China and Nepal is more than the U.S.A. On the contrary, the contribution of service in GDP of both China and Nepal is less than the U.S.A. while the contribution of industry in GDP of China is more than both the U.S.A. and Nepal (www.cia.gov).

\section{Main Agricultural and Industrial Products}

The major agriculture products of China are rice, wheat, potatoes, corn, tobacco, peanuts, tea, apples, cotton, pork, mutton, eggs, fish, and shrimp and world leader in gross value of agricultural output. At the same time, the major industrial products of China are mining and ore processing, iron, steel, aluminum, and other metals, coal, machine building, armaments, textiles and apparel, chemicals, fertilizer, petroleum, cement, consumer products (including toys, footwear, and electronics), food processing, transportation equipment, including automobiles, railcars and locomotives, ships, aircraft; telecommunications equipment, commercial space launch vehicles, satellites and world leader in gross value of industrial output (www.cia.gov). Similarly, major agriculture products of the U.S.A. are wheat, corn, other grains, fruits, vegetables, cotton; beef, pork, poultry, dairy products, fish, and forest products. While major industrial products of the U.S.A. are highly diversified like petroleum, steel, motor vehicles, aerospace, telecommunications, chemicals, electronics, food processing, consumer goods, lumber, mining and second largest industrial output in the world. Accordingly, major agriculture products of Nepal are pulses, rice, corn, wheat, sugarcane, jute, root crops; milk, water buffalo meat, while major industrial products of Nepal are tourism, carpets, textiles, small rice, jute, sugar, and oilseed mills, cigarettes, cement and brick production.

\section{Direction of Foreign Trade}

The foreign trade of China has remained dynamic since last four decades. Until the $19^{\text {th }}$ century, a large volume of foreign trade was directed towards the Great Britain and Japan. In general economic system of China after 1949 was modeled as the Soviet Union and increased savings from the rural sector in order to benefit industrial production. The quantitative information the foreign trade of China during the period 1949-79 is very limited. The share of China in the world trade did not change much between 1970 and 1978 whereas after 1978 the share of China increased significantly and also consistent with a trade liberalizing impact of the 1978 reforms. Between 1978 and1990, trade growth was 7.5 percent and between 1990 and 2000, it became 13.5 percent, and between 2000 and 2007, it was 16.2 percent. An important event that strengthened the foreign trade of China is its accession to the WTO in the year 2001 (Keller, Li \& Shiue, 2010). Similarly, the ratio of global trade growth also increased overtime. It can be explained as given below. 
58 I The Economic Journal of Nepal (Issue No. 148)

Figure 2: Exports of Goods and Services as a Percent of GDP

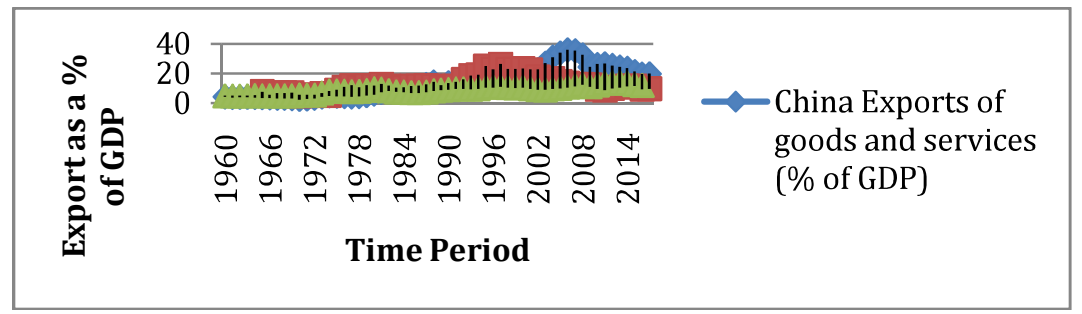

Source: World Development Indicators, World Bank, 2017.

The figure 2 shows that the growth path of exports in percent of GDP of China is linear since 2002 to 2008 and it becomes slow down. But the growth path of exports in percent of GDP of USA is almost constant and stable. The correlation of export of China and the U.S.A. is equal to 0.81 that implies not perfect correlation between them. On the contrary, the growth path of exports in percent of GDP of Nepal became linear after 1990 up to 1996 and it is steeper. It implies that more growth in exports in that time. Similarly, Nepalese growth path of exports is gradually decreasing since 1996 up to 2010 and remains almost low. It implies that Nepal is far behind from economic achievement.

Figure 3: Imports of Goods and Services in Percent of GDP

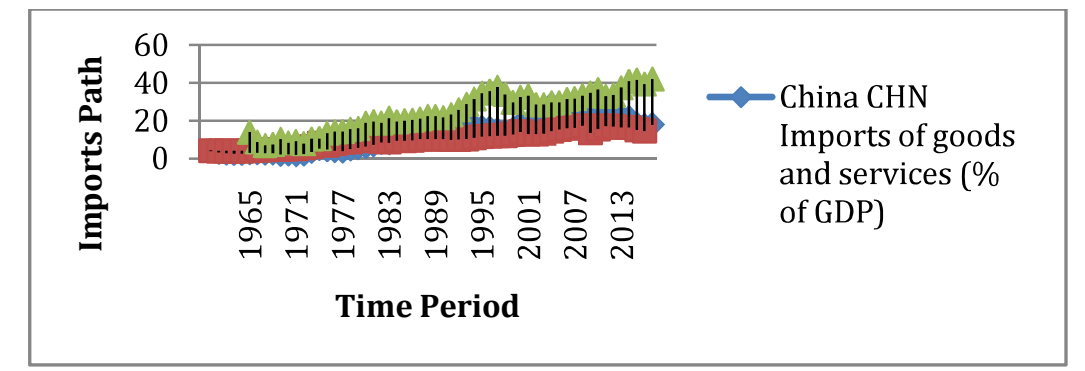

Source: World Development Indicators, World Bank, 2017.

Similarly, the growth path of imports as a percent of GDP of China, U.S.A. and Nepal has been increased continuously from 1960. But increasing ratio of Nepal is quit higher than China and the U.S.A. The correlation of export of China and the U.S.A. is equal to 0.93 percent that implies a higher correlation. Similarly, the growth path of Nepal is tremendously higher than both China and the USA. It implies that the foreign trade of Nepal moves towards unfavorable situation, which may mislead to the nation for go ahead.

Table 3: GDP Composition (by end of 2017 in percent)

\begin{tabular}{|l|l|l|l|}
\hline Sectors / Countries & China & USA & Nepal \\
\hline HH Consumption & 39.1 & 69.1 & 76.2 \\
\hline Government Consumption & 14.6 & 17.2 & 11.7 \\
\hline Investment in fixed Capital & 43.3 & 16.3 & 33.8 \\
\hline Investment in Inventories & 1.1 & 0.3 & 10.5 \\
\hline Exports of Goods/Services & 19.7 & 12.2 & 9.8 \\
\hline Imports of Goods/Services & -17.8 & -15.1 & -42 \\
\hline
\end{tabular}

Source: www.cia.gov. 
The table 3 shows that exports of goods/s on the basis of GDP composition of China are far better than the U.S.A. and Nepal. At the same time, import of goods/s on the basis of GDP composition of China is lesser than exports, but this is just opposite in case of U.S.A. Nepal, where imports composition is extremely higher than exports. Accordingly, investment in fixed capital of China is higher than U.S.A. and Nepal, which results future secure for further development. It implies that Chinese economy is more strong and competitive in an international market.

\section{Structure of Exports and Imports}

The major exports of China is electrical and other machinery including computers and telecommunications equipments, apparel, furniture, textiles whereas the major imports are electrical and other machinery including integrated circuits and other computer components, optical and medical equipment, oil and mineral fuels, metal ores, motor vehicles and soybeans. In 2016, China exported US \$ 2.27 trillion and imported US \$1.23 trillion that results a positive trade balance of US \$1.04 trillion. In 2016, the GDP of China was US $\$ 11.2$ trillion and its GDP per capita was US \$15.5 thousands. The top exports of China are computers (US \$173 billion), broadcasting equipment (US \$ 160 billion), telephones (US \$ 109 billion), integrated circuits (US $\$ 64.6$ billion) and official machinery parts (US $\$ 42.8$ billion) respectively using the 1992 revision of the HS (Harmonized System) classification. Similarly, its top imports are crude petroleum (US \$ 101 billion), integrated circuits (US \$ 98.3 billion), gold (US \$ 51.2 billion), iron ore (US $\$ 47.4$ billion) and cars (US $\$ 42.7$ billion). It implies that export domination foreign trade of China (OEC, 2017).

Similarly, the major exports commodities of the U.S.A. are agricultural products like fruits, soybeans, corn (9.2 percent), industrial supplies like organic chemicals (26.8 percent), capital goods like transistors, aircraft, motor vehicle parts, computers, telecommunications equipment (49.0 percent), consumer goods like automobiles, medicines (15.0 percent) (www.cia.gov). While in 2016, the major exports of USA are capital goods (34.34 percent), consumer goods (25.53 percent), machines and electronics (24.01 percent), intermediate goods (19.59 percent), chemicals (10.56 percent) and transportation (9.94 percent) respectively (WITS, 2017). At the same time, the major imported commodities are capital goods like computers, telecommunications equipment, motor vehicle parts, office machines, electric power machinery (30.4 percent), agricultural products (4.9 percent), industrial supplies (32.9 percent), consumer goods like automobiles, clothing, medicines, furniture, toys (31.8 percent) (CIA, 2008). While in 2016, major imports of the U.S.A. are consumer goods (37.75 percent), capital goods (34.53 percent), intermediate goods (15.44 percent), raw materials (8.42 percent) (WITS, 2017).

Similarly, major exported commodities of Nepal are clothing, pulses, carpets, textiles, juice, jute goods whereas the major imported commodities are petroleum products, machinery, equipment, gold, electrical goods, and medicine (www.cia.gov). At the same time, exported items are consumer goods (54.68 percent), intermediate goods (36.53 percent), raw materials (6.97 percent) and capital goods (1.78 percent) (WITS, 2017), while imported items are intermediate goods (35.37 percent), consumer goods (33.47 percent), capital goods (20.55 percent) and raw materials (10.59 percent) respectively (WITS, 2017). It implies that poor performance of export and import of Nepal. 
Table 4: Exports, Imports and Trade Ratio to GDP (in 2016)

\begin{tabular}{|l|l|l|l|}
\hline Description & China & USA & Nepal \\
\hline Exports in percent of GDP & 19.66 & 11.89 & 9.49 \\
\hline Imports in percent of GDP & 17.38 & 14.69 & 39.38 \\
\hline Total Trade of goods /s in percent of GDP & 37.04 & 26.58 & 48.87 \\
\hline Total Trade in Services in percent of GDP & 5.81 & 6.75 & 12.33 \\
\hline
\end{tabular}
Source: World Bank, 2017.

Since the exports to GDP of China is more than imports to GDP in 2016. It implies that Chinese foreign trade moving towards exports rather than imports. So, they are able to accumulate more capital through external sector. In comparison to the U.S.A. and Nepal, it is opposite to China. It means foreign trade of the U.S.A. and Nepal are moving towards imports rather than exports. But in case of Nepal, it has severe effects of large gap between exports and imports in percent of GDP i.e. 29.89 percent (Imports 39.38 percent - Exports 9.49 percent). Accordingly, total trade in percent of GDP of Nepal is more than China and the U.S.A. It means the Nepal is focusing more in trading than manufacturing.

\section{Causes of Trade War between China and the U.S.A.}

There are various causes of trade disputes between China and the U.S.A. Politicians of the U.S.A. have long threatened a trade war with their largest trading partner. A trade deficit occurs when imports are more than exports. In 2017, the U.S.A. exported US \$130 billion to China. The three largest export categories are aircraft at US $\$ 16$ billion, soybeans, US $\$ 12$ billion, and automobiles US \$11 billion. Similarly, the U.S.A. imported from China was US $\$ 506$ billion. Most of them were electronics, clothing, and machinery. But a lot of imports are from U.S.A. manufacturers that send raw materials to China for low cost assembled. Once dispatched back to the U.S.A. they are considered imports. As a result, tariffs hurt U.S.A. corporations as well as foreign ones. China is the number one exporter of the world. Their comparative advantages are that it can produce consumer goods for lower costs than other countries. China has lower living standards, which allow its companies to pay lower wages. That is why American companies cannot compete with low costs of China. So, it loses U.S.A. manufacturing. Of course, Americans want these goods for the lowest prices. Most are not willing to pay more for 'Made in America' (Amadeo, 2017).

President Trump says that the trade wars are good and easy to win. Trump used a special power granted by Congress in 1962 to impose tariffs even in the Congress is the only authorized body. It allows a president to reduce imports that make threats national security of US. As a report of commerce department of the U. S. A., its ability to make weapons threats due to dependence on imported metals. William Overholt, a senior fellow at the Harvard University Asia Center, says "problem of Trump is that he has demanded the structural transformation of the Chinese economy into something that works more like the U.S. economy and his administration has defined China as our economic and military enemy', 'The demand is nonnegotiable and everyone in both China and the U.S.A. knows it'. Such trade principle supports a mercantilist philosophy. It promotes specific industries that are important for the purposes of political leaders. Pork growers tend to vote Republican, which is why China targeted their exports. The telecom industry is a part of Chinese growth strategy which is one reason why Trump imposed tariffs. The other is that the company violated U.S. sanctions against Iran and North Korea. 


\section{Consequences_of Trade War between China and the U.S.A.}

In the short run, it has positive impact on trade, which helps to become cheaper for domestic products and increases profit of domestic producers. But in the long run, it causes inflation when tariffs increase the prices of imports that slowdowns potential economic growth for all countries involved. So, a trade war costs growth and employment (Amadeo, 2017). They create more layoffs, not fewer, as foreign countries hit back. The 12 million American workers who owe their jobs to exports could get laid off. As a consultant of Oxford Economics predicted that the trade war between China and the U.S.A. could cost the overall economy by US $\$ 800$ billion. That could slow growth by 0.4 percent. It is occurring at the same time that oil prices and interest rates are rising. In general, trade wars weaken the protected domestic industries. Companies within the industry don't need to innovate without foreign competition. Eventually, the home product would decline in quality compared to foreign goods. It can be further explained as follows:

\section{Effects in the USA Economy}

The trade war has increased the prices of consumer goods that use steel and aluminum. Almost 50 percent of total imported goods from China are being used by American manufacturers to make other products. So, tariffs raise their costs of production and forcing them to either raise prices or lay off workers. Soda and Beer suppliers were the first to raise prices. Costs have increased on imported clothes hangers, heavy equipment materials, computer chips and tool makers. At the same time, according to the Aerospace Industrial Council (AIC), tariffs policy of Trump Administration would instead raise costs for the military and exporters. The Alliance of Automobile Manufacturers warned that U.S. produced steel will cost more. So, it creates threatening the global competitiveness and raising vehicle costs for the customers in a market. The Maine lobster industry will suffer from Chinese penalizing tariffs on U.S. seafood. California cheese makers are already seeing their markets in China and Mexico disappear due to penalizing tariffs. Wisconsin auto parts manufacturers and the U.S. bourbon industry are other industries being punished.

The U.S.A. imports of many types of goods from China that are originated in the U.S.A. Raw materials are sent to China for processing and then exported finished goods back to America like salmon from Alaska sent to China for processing, and back to U.S. grocery shelves. If Trump Administration imposes tariffs on seafood imports, it will raise prices by 25 percent to 50 percent. Foreign tariffs on U.S. exports will make them more expensive. American exporters may have to cut costs and lay-off workers to remain competitively priced. If they fail, they may cut costs further or even go out of business. China will also levy tariffs on American agricultural exports. Midwest farmers could be stuck with excess produce and livestock. President Trump announced that he would offer US \$12 billion in subsidies to American farmers. On $27^{\text {th }}$ August, the Trump Administration announced US \$ 4.7 billion assist. It may make a second payment in December if it is still needed. But corn growers alone said their costs top US \$ 6 billion. It could also threaten U.S. oil exports. China buys 20 percent of U.S. oil exports.

\section{Effects in Chinese Economy}

President Trump asked to China to develop a plan to reduce the US trade deficit by US \$ 100 billion from US $\$ 375$ billion. China is agreeable to the idea. That is why the part of plan for economic reform of China is to shrink its dependence on exports. But it cautions there is not much it can do, since the deficit is fueled by high US demand for low-cost Chinese 
goods. China will get revenge by adding tariffs on US $\$ 60$ billion of exports in the USA. In response, Trump threatened to add tariffs until all US $\$ 500$ billion of Chinese imports are affected. That could reduce economic growth by 0.75 points. The USA is a major destination of Chinese exports i.e. more than 5 trillion. If the USA followed protection trade policy then that causes reduction of Chinese domestic production. As the Washington Post reported that due to the tariff hike by the Trump Administration, Chinese goods have become dearer in the US.

The price of household appliances and cell phones imported from China surged by 8 percent over the past year.

\section{Increase in Regional Trade}

There are three different main trade blocks in the world i.e. North America, Europe and East Asia. Due to protection trade, the USA increases their trade towards Europe, China and East Asia. The economy of Europe is developed and East Asia refers emerging economy. So, China will be more benefited than the USA in this regard.

\section{Dumping Policy of China}

Due to growing economy, China is able to produce low-priced goods/s. On the basis of such potential capacity, China may focus on dumping policy and increases export of goods/s in developing countries of Asia and Africa. On the contrary, the USA is unable to follow such policy of dumping due to expensive economy.

\section{Trade Promotion through Donor Agency}

As a largest donor country, the USA may promote exports through their donor line agencies. In this case, the USA is more benefited than China, but China is rapidly followed the USA as a major country.

\section{Effects on Currency}

If the tariff war goes on and the scale of US tariffs on Chinese goods increases, then China will put up for sale its treasuries. China can respond most obviously by finding ways to penalize and punish US firms operating in China. At the same time, US tariffs will lower its exports, it is quite conceivable that China might want to manage its currency down and intentionally depreciate its currency and China probably has the capacity to do that. It need not be a Chinese announcement that they are depreciating the currency for trade purposes. It could just be that there are market pressures that materialize to push the currency down, and China permits that to happen. The USA should be worried as China to let its currency weaken and that is very difficult for the USA to counter. Therefore, the fall in Chinese investment in the USA due to simply as a function of USA policy causes Chinese investors for looking to move money out of China as their expectations that the Yuan is going to fall.

\section{Direction of Trade after Trade Disputes}

Tariff policy of USA went into effect for US \$34 billion of Chinese imports. China levied a 40 percent of tariff on US automobiles. It could threaten the exports of American cars that employ thousands of workers in the South. Some American companies announced that it could build a factory in China to avoid the tariff. Shortly afterward, China canceled all US soybean import contracts. China imports US $\$ 12$ billion in US soybeans. China needs 
soybeans to feed pigs, its primary meat staple. But China can replace US beans with those from Brazil. US farmers sell one-half of their crops to China. If that market disappears, it will hurt the US more than China. Soybean prices hit a 10-year low as analysts predicted oversupply. Another sign of a sudden change is that Chinese investments in the US declined due to US curtail Chinese tech investments. In the beginning of 2017, the Chinese enforce their own capital controls for their own reasons and they decreased significantly on outward direct investment. Accordingly, observation of monthly data of 5 years from 2013 to 2017, both exports and imports in millions of US \$ has been continuously increasing up to 2015 A.D. But it is slightly declined in 2016 A.D. Similarly, after that imports of USA is in increasing trend while export is in decreasing trend. It means that trade disputes directly hurt American exports to China rather than American imports from China.

\section{Effects in Nepalese Economy}

As a least developed country, Nepal has been granted tariff free and quota free facilities to exports to the USA under the 'Generalized System of Preference Facility'. Similarly, China has granted duty free and quota free facility to 8,030 products for LDCs. Though the exports of Nepal base is weak and its exports to the USA and China are being carried out under the duty free facility, tariffs raised by the USA and China to discourage imports from countries to each other that will adversely affect the exports from Nepal as the products cannot be competitive in the USA and Chinese markets due to high tariff walls. Industries that are in the production linkages with the developing countries can be affected if the export of the goods produced from those production linkages slides. As trade concentration of Nepal is with India and its exports to the USA, China and European Union are under the tariff free and quota free facilities. The country will not face a direct impact of the trade war between China and USA However, protectionist policy adopted by the developed countries will have long-term impact on global trade and investments. As experts say that the annual exports of Nepal is expected to around Rs. 80 billions in this fiscal year and there will not be significant impact on the trade war between those two economic. Again, experts have said that losing purchasing power of Nepalese Rupee vis-a-vis US $\$$ has further increased the trade concentration with India as imports will be relatively cheaper in India due to fixed exchange rate regime compared to other countries.

\section{Effects on Foreign Trade with China}

It is found that 12.63 percent of total imports and 3.01 percent of total exports are carried out with China (WITS, 2017). Similarly, China is a second largest partner of imports and sixth partner of exports of Nepal. The linkages of Nepalese industries in the production network of China are also weak.

Table 5: Status of Foreign Trade with China (Rs. in 10 millions)

\begin{tabular}{|c|c|c|}
\hline Description & Exports of Nepal to China & Imports of Nepal from China \\
\hline $2012 / 13$ & 208.6 & 6245.1 \\
\hline $2013 / 14$ & 284.1 & 7331.9 \\
\hline $2014 / 15$ & 223 & 10016.6 \\
\hline $2015 / 16$ & 168.2 & 11569.4 \\
\hline $2016 / 17$ & 170.1 & 12724.5 \\
\hline
\end{tabular}

Source: MoF, 2017. 
The table 5 shows that imports from China are continuously increasing, while exports are decreasing after 2014/15 and slightly increased in 2016/17. It means trade war effects on our exports. But there is no need to worry about it because the exports of Nepal to the northern neighbor is weak as the country has not been able to exploit the duty free and quota free facilities that extended to Nepal. Similarly, the exported items of Nepal are lesser than imported items with China. Almost every item of imports has been continuously increasing, while exports of every item do not increase and some items became nil over a time period. Therefore, our exports or exportable items are not sustainable. That is why Nepal has to select competitive goods to increase exports and in the same time should aware from dumping policy of China due to high imports.

\section{Effects on Foreign Trade with the USA}

It is found that 11.15 percent of total exports and 0.82 percent of total imports are carried out with US (WITS, 2017). Similarly, US is a second largest export partner and tiny partner of imports of Nepal along with linkages of the Nepalese industries in the production network of US are also weak.

Table 6: Status of Foreign Trade with U.S.A. (US $\$$ in millions)

\begin{tabular}{|c|c|c|}
\hline Fiscal Years & Exports of Nepal to the USA & Imports of Nepal from the USA \\
\hline $2007 / 08$ & 89.9 & 29 \\
\hline $2008 / 09$ & 84.9 & 28.5 \\
\hline $2009 / 10$ & 54.7 & 31 \\
\hline $2010 / 11$ & 60.5 & 28.3 \\
\hline $2011 / 12$ & 77.4 & 40.4 \\
\hline $2012 / 13$ & 83.5 & 37 \\
\hline $2013 / 14$ & 77.8 & 32.5 \\
\hline $2014 / 15$ & 87.2 & 36.3 \\
\hline $2015 / 16$ & 87 & 36.4 \\
\hline $2016 / 17$ & 88.6 & 40.5 \\
\hline
\end{tabular}

Source: USCB (United States Census Bureau), 2017

The table 6 shows exports of Nepal to the USA are decreasing up to 2009/10 but increased up to 2012/13. Again, it started decrease and there after increased. It means that trade war does not affect on exports of Nepal to the USA while imports from USA, it suddenly increased in 2017. So, both exports to and imports from Nepal to USA are almost volatile in which imports are more volatile than exports. Similarly, So, Nepal has to sustain and further increased exports to USA. At the same time, Nepal should aware from donor policy of US to increase their exports.

\section{Discussion}

Historically, there has been trade relationship between China and the USA along with Nepal. Recently, there is a trade dispute in between China and the USA due to trade policy of both countries. Even though USA imposed tariffs and quotas on imported Chinese goods due to huge trade deficit with China i. e. more than 3 trillion for trade protection. Similarly, there us trade surplus of Nepal with the USA while huge deficit with China. 


\section{Summary}

Trade imbalances between China and the USA have become a major concern of global macro economics. But twenty first century is an important period of dynamic change for international trade as trade liberalization and domestic economic reforms coincided with growing interdependence in the world economy through trade and capital flows. The trade war has positive influence on trade in the short run, despite the fact that in the long run, it slows both economic growth and employment and that increases oil prices along with interest rates. Over time period, trade wars weaken the protected domestic industry due to lack of free competition that causes decline in quality compared to foreign goods/s.

\section{Interpretation}

On the basis of comparative analysis of 58 years of foreign trade data observations, there is significant and positive correlation between China and the USA Similarly, trade war occurs due to huge trade deficit of USA with China i.e. more than 3 trillion US \$. As the President Trump says, 'The trade wars are good and easy to win' and the structural transformation of the Chinese economy into something that works more like the USA economy. Accordingly, trade war affects in domestic production of both China and the USA and trade direction moves towards regional trade and thereby overall nature and volume of international trade, Chinese trade policy gives attention to dumping policy and devaluation of Chinese currency. As exports of Nepal are expected of dumping to around 1 billion US $\$$ in this fiscal year, which is significantly small amount. Similarly, there is decreased in exports to China due to the trade war between the two economic giants, even though it does not have an effect on trade with USA.

\section{Implications}

If trade disputes increases, then foreign investments of both countries in each other are declined. China focused their trade towards East Asia and Africa, while the U.S.A. focused on Europe. Due to low cost of production, China uses dumping policy to expand foreign trade in developing countries of Asia and Africa. If trade war enlarged, Chinese currency will be devaluated that is very difficult for the U.S.A. to counter. It may also affects on the situation of Nepalese trade surplus with USA. In the short run, U.S.A. is benefited than China, but in the long run, it hurts both economies along with global economy.

\section{References}

Amadeo, K. (2017). US trade deficit with China. Retrieved from https://www.thebalance.com/u-s-china-trade-deficit-causes-effects-and-solutions3306277.

Amadeo, K. (2017). Trade wars and how they affect you. Retrieved from https://www.theba lance.com/trade-wars-definition-how-it-affects-you-4159973.

Auer, R., \& Fisher, A. M. (2010). The effect of low-wage import competition on U.S. inflationary pressure. Journal of Monetary Economics, 57 (4): 491-503. Retrieved from https://doi.org/10.1257/aer.20141419.

Handley, K. \& Limao, N. (2017). Policy uncertainty, trade and welfare: Theory and evidencefor China and the United States. American Economic Review, 107(9), 27312783. Retrieved from https://doi.org/10.1257/aer.20141419. 
66 I The Economic Journal of Nepal (Issue No. 148)

Keller, W., Li, B., \& Shiue, C. H. (2010). China's foreign trade: Perspectives from the past 150 years. NBER Working Paper No. 16550.

MoF (Ministry of Finance) (2017). Economic Survey FY - 2016/17. Government of Nepal, Ministry of Finance. Kathmandu.http://en.wikipedia.org/wiki/trade.

World Bank (2017). Annual Reports. Retrieved from http://www.worldbank.org/en/ about/annual- report/world-bank-group-downloads

WITS (World Integrated Trade Solution) (2017). China Trade Statistics. WITS. Retrieved from https://wits.worldbank.org/countryprofile/en/chn

......(2017). US Trade Statistics. WITS. Retrieved from https://wits.worldbank.org/ CountryProfile/en/Country/CHN/Year/LTST/TradeFlow/EXPIMP/Partner/bycountry.

......(2017). Nepal Trade Statistics. WITS. Retrieved from https://wits.worldbank.org/ CountryProfile/en/NPL

OCE (2017). Observatory Economic Complexity. Retrieved from https://atlas.media.mit.edu/en/profile/country/chn/\#Exports

Electronic Source

www.cia.gov

www.worldbank.org 